\title{
Determination of Iron and Zinc Absorption by Local Isolates of Saccharomyces cerevisiae to Produce Iron and Zinc in Organic Form
}

\author{
Hasim Munawar ${ }^{1}$, Eni Kusumaningtyas ${ }^{2}$, Agus Leeman $^{3}$, David S. Silitonga ${ }^{3}$, and Darmono ${ }^{1,3}$ \\ 1Toxicology Laboratory, Indonesian Research Centre for Veterinary Science (IRCVS) \\ 2bMycology Laboratory, Indonesian Research Centre for Veterinary Science (IRCVS) \\ Jalan R.E. Martadinata No 30 Bogor16114 Indoensia, tlp: 0251-8331048, fax: 0251-8336425 \\ 3cFaculty of Pharmacy, Pancasila University \\ Srengseng Sawah, Jagakarsa Jakarta 12640 Indonesia tel: +62 217864725 fax: +62 217864723 \\ Email: seemunawar@gmail.com
}

\begin{abstract}
Iron $(\mathrm{Fe})$ and Zinc $(\mathrm{Zn})$ play important role in health both of live stock and human. Fe and $\mathrm{Zn}$ in organic form were claimed increasing their viabilities. They bind to certain amino acid formed as a product of microbial metabolism. The Amount Fe and $\mathrm{Zn}$ absorbed may indicated the $\mathrm{Fe}$ and $\mathrm{Zn}$ organic produced. The aim of the study is to determine the absorption of microelement of $\mathrm{Fe}$ and $\mathrm{Zn}$ by local isolates of Saccharomyces cerevisiae to produce Fe and Zn in organic forms. S. cerevisae BCC F0205, BCC F0206, and BCC F0214 were treated with Fe or Zn 10 ppm to obtain S. cerevisae which has the highest of total concentration of $\mathrm{Fe}$ and $\mathrm{Zn}$. Selected isolate was then treated with $\mathrm{Fe}$ or $\mathrm{Zn}$ respectively 2.5, 5, $10 \mathrm{ppm}$ and their combination. $\mathrm{Fe}$ and $\mathrm{Zn}$ absorbed by isolates were measured by Atomic Absorption Spectrophotometer (AAS). The results show that S. cerevisae BCC F0205, BCC F0206, and BCC F0214 treated with $10 \mathrm{ppm} F e$ or $\mathrm{Zn}$ contained total concentration of Fe respectively 1.57, 3.07, $2.24 \mathrm{ppm}$ and total concentration of $Z n$ respectively 2.34, 3.20, $3.13 \mathrm{ppm}$. Then, S. cerevisae BCC F0206 treated with 2.5, 5, $10 \mathrm{ppm} \mathrm{Fe}$ or $\mathrm{Zn}$, absorbed Fe 1.45, 0.50, $0.94 \mathrm{ppm}$ and $\mathrm{Zn} 0.73,0.38,0.53 \mathrm{ppm}$ respectively. Furthermore, combination of $\mathrm{Fe}$ and $\mathrm{Zn}(2.5: 2.5,5: 5,10: 10 \mathrm{ppm})$ produce absorption of Fe 3.10, 2.13, $3.67 \mathrm{ppm}$ and $\mathrm{Zn} 0.11,0.10,0.28 \mathrm{ppm}$ per gram S. cerevisae BCC F0206. Percentages of absorption by $S$. cerevisae are up to $100 \%$ for $\mathrm{Fe}$ and up to $47.20 \%$ for $\mathrm{Zn}$. In conclusion, this study indicated that $S$. cerevisae BCC F0206 absorb Fe and Zn higher than BCC F0205 and BCC F0214 and there are antagonistic interactions found between $\mathrm{Fe}$ and $\mathrm{Zn}$ in this research.
\end{abstract}

Keywords: Saccharomyces, yeast, iron, Zinc, Absorption

\section{Abstrak}

Besi ( $\mathrm{Fe}$ ) dan Seng $(\mathrm{Zn})$ berperan penting dalam kesehatan hewan ternak dan manusia. Fe dan $\mathrm{Zn}$ dalam bentuk organik diakui meningkatkan viabilitasnya. Fe dan $\mathrm{Zn}$ mengikat asam amino tertentu yang terbentuk sebagai produk dari metabolisme mikroba. Jumlah Fe dan Zn diserap dapat menunjukkan Fe dan Zn dalam bentuk organik yang dihasilkan. Tujuan dari penelitian ini adalah menentukan penyerapan mikronutrien Fe dan Zn oleh isolat lokal Saccharomyces cerevisiae untuk menghasilkan Fe dan Zn dalam bentuk organik. S. cerevisiae BCC F0205, BCC F0206, dan BCC F0214 dberi perlakuan dengan menambahkan $\mathrm{Fe}$ atau $\mathrm{Zn} 10 \mathrm{ppm}$ untuk mendapatkan S. cerevisiae yang memiliki konsentrasi total $\mathrm{Fe}$ dan $\mathrm{Zn}$ tertinggi. Isolat yang dipilih kemudian di beri perlakuan dengan Fe atau Zn masing-masing 2,5; 5; 10 ppm dan campurannya. Fe dan Zn diserap oleh isolat diukur dengan Spektrofotometer Serapan Atom (AAS). Hasil penelitian menunjukkan bahwa S. cerevisiae BCC F0205, BCC F0206, dan BCC F0214 yang sudah diberi perlakuan dengan $10 \mathrm{ppm} F e$ atau $\mathrm{Zn}$ mengandung konsentrasi total Fe masingmasing 1,57, 3,07, 2.24 ppm dan konsentrasi total Zn masing-masing 2.34, 3.20, 3.13 ppm. Kemudian, S. cerevisiae BCC F0206 diberi perlakuan lanjut dengan 2,5; 5; 10 ppm Fe atau Zn, sehingga Fe yang terabsorpsi masing-masing $1,45,0,50,0,94 \mathrm{ppm}$ dan $\mathrm{Zn}$ masing-masing $0,73,0,38,0,53 \mathrm{ppm}$. Kemudian,kombinasi Fe dan Zn (2,5:2,5, 5:5, $10: 10$ ppm) menghasilkan penyerapan Fe 3.10, 2.13, 3.67 ppm dan Zn 0,11, 0,10, 0,28 ppm per gram S. cerevisiae BCC F0206. Persentase absorpsi dari S. cerevisae adalah hingga $100 \%$ untuk Fe dan hingga 47,20\% untuk Zn. Kesimpulan dari penelitian ini adalah S. cerevisiae BCC F0206 menyerap Fe dan Zn lebih tinggi dari BCC F0205 dan F0214 BCC dan interaksi antagonistik ditemukan antara Fe dan Zn dalam penelitian ini.

Kata kunci: Saccharomyces, ragi, besi, seng, absorpsi 


\section{Introduction}

Iron $(\mathrm{Fe})$ is a micronutrient that has been used critically in blood cells and enzymes formations. In a body, around 55\% of $\mathrm{Fe}$ form complex compounds with haemoglobin that play in metabolism process (King, 2006). In addition, Fe also form ferritin, transferrin and haemosiderin as nutrient reservation placed in hepatocytes in liver tissue (Nadadur et al. 2008). Other functions of $\mathrm{Fe}$ are to activate reticuloendothelial system that will prevent liver dysfunction (Knutson \& WesslingResnick 2003, Maliken et al. 2013) and play in nervous and immune systems (Arredondo \& Nunez 2005). If deficiency of $\mathrm{Fe}$ is occurred, it will cause anaemia and trigger other diseases due to there are interactions with heavy metals, lead $(\mathrm{Pb})$ and cadmium (Cd), which will shift the binding of Fe with a number of proteins (WHO et al. 2001).

Not only $\mathrm{Fe}$, but Zinc (Zn) is also a micronutrient that plays an important role in enzyme formations and metabolic process. More than 300 enzymes containing $\mathrm{Zn}$ are used in carbohydrate metabolism as source of energy and in catalytic system, especially on synthesis of DNA, RNA and protein (Sillerova et al. 2012). Then, $\mathrm{Zn}$ is also important in cell signalling, apoptosis, lipid metabolism, immune and brain system, as well as development and growth (Ackland \& Michalczyk. 2006). If concentration of $\mathrm{Zn}$ in the body is less, it will cause problems in reproductive and immune systems (Widhyari, 2012; King, 2000, Kumar et al. 2011). Moreover, Zn deficiency will affect to decrease absorption of water and electrolytes substances by intestine and also to increase secretion that will cause dehydration (Roy et al. 2006).

To overcome deficiency of minerals has been done which is provision of salt mixed with feed. In other studies, administrations of mineral blocks are able to increase body weight of cow up to $370 \mathrm{~g} /$ day compared to cows without mineral blocks (Addai, 2014). Currently, the application of Saccharomyces cereisiae is used widely for feed supplement. Perone et al. (2013), revealed that $S$ cerevisiae could trigger bone development by measuring closure of distal radius growth plate and other parameters such as alkaline phosphatase, calcium and magnesium for some horses at 24 months of age. In other cases, provision of $S$ cerevisiae in pigs (pregnancy lactation) could reduce weaning to estrus internal (WEI) and increase lgG in colostrum (Jang et al. 2013) while provision of $S$ cerevisiae to laying hens improved egg weight and increased efficiency of feeding. $S$. cerevisiae could be applied as a medium for preparation of organic minerals which are more effective to absorb by livestock (Hegoczki, 1994). Therefore, the aim of study is to determine the absorption of microelement Fe and $\mathrm{Zn}$ by local isolates of Saccharomyces cerevisiae to produce $\mathrm{Fe}$ and $\mathrm{Zn}$ in organic forms.

\section{Materials and methods}

\section{Preparation of Saccharomyces cerevisae}

All isolates of $S$. cerevisae were obtained from BBlitvet Culture Collection (BCC), namely BCC F0205, BCC F0206 and BCC F0214. Isolates were grown in Sabouraud dextrose agar (SDA) medium and incubated at $25^{\circ} \mathrm{C}$ for $48 \mathrm{~h}$. Furthermore, each isolate was inoculated into $200 \mathrm{ml}$ of Potato dextrose broth (PDB) medium and incubated at $25^{\circ} \mathrm{C}$ for $48 \mathrm{~h}$. Concentration of $\mathrm{Fe}$ and $\mathrm{Zn}$ per gram $S$ cerevisae naturally was measured by AAS. Then, concentration of $S$. cerevisae was adjusted to $10^{7} \mathrm{CFU} / \mathrm{ml}$ in $200 \mathrm{ml}$ of PDB medium for next treatments.

\section{Screening of $S$. cerevisiae isolates containing the highest concentration of Fe and $\mathrm{Zn}$}

Each $S$ cerevisae was treated with 10 ppm of Fe or $\mathrm{Zn}$ and incubated at $37^{\circ} \mathrm{C}$ for 48 $h$. Then, the total of Fe or $Z n$ per gram $S$. cerevisae was measured by AAS. Each treatment was made three replications. The isolate that had the highest concentration of $\mathrm{Fe}$ or $\mathrm{Zn}$ was selected for further experiment.

\section{Optimization Fe or $\mathrm{Zn}$ absorption}

Suspension of $S$. cerevisiae with concentration $10^{7} \mathrm{CFU} / \mathrm{ml}$ in $200 \mathrm{ml}$ of PDB medium were treated as shown in Table 1 , and incubated at $37^{\circ} \mathrm{C}$ for $48 \mathrm{~h}$ with shaking $150 \mathrm{rpm}, 1 \mathrm{~h}$ for 4 times. The ability of selected isolate to absorb $\mathrm{Fe}$ and $\mathrm{Zn}$ was measured by AAS (Munawar, 2011). The absorbed concentration of $\mathrm{Fe}$ or $\mathrm{Zn}$ by selected isolate can be calculated as followed: 


\section{Absorbed concentration $=$ Detected concentration - Natural concentration}

Table 1 Composition of treatment on selected isolates

\begin{tabular}{|c|c|}
\hline Treatment & Composition \\
\hline Blank & PDB + S. Cerevisiae \\
\hline SZn1 & $\mathrm{PDB}+$ S. cerevisiae + Zn $2.5 \mathrm{ppm}$ \\
\hline SZn2 & PDB + S. cerevisiae + Zn 5 ppm \\
\hline SZn3 & PDB + S. cerevisiae + Zn 10 ppm \\
\hline SFe1 & $\mathrm{PDB}+$ S. cerevisiae + Fe $2.5 \mathrm{ppm}$ \\
\hline SFe2 & $\mathrm{PDB}+$ S. cerevisiae + Fe $5 \mathrm{ppm}$ \\
\hline SFe3 & PDB + S. cerevisiae + Fe 10 ppm \\
\hline SZnFe1 & $\mathrm{PDB}+$ S. cerevisiae + Zn $2.5 \mathrm{ppm}+\mathrm{Fe} 2.5 \mathrm{ppm}$ \\
\hline SZnFe2 & $\mathrm{PDB}+$ S. cerevisiae + Zn 5 ppm + Fe 5 ppm \\
\hline SZnFe3 & $\mathrm{PDB}+$ S. cerevisiae + Zn 10 ppm + Fe 10 ppm \\
\hline
\end{tabular}

\section{Determination of $\mathrm{Fe}$ and $\mathrm{Zn}$ concentration}

S. cerevisae was collected by centrifugation at $3000 \mathrm{rpm}$ for 15 minutes. These pellets obtained were weighed and soaked with $10 \mathrm{ml}$ concentrate nitric acid $\left(\mathrm{HNO}_{3}\right)$ for 24 hours. The solutions were heated approximately 2 - 4 hours to obtain colorless solutions and $2 \mathrm{ml}$ remaining volume. Furthermore, the solutions were filtered by Whatman filter paper No. 42, poured in a flask $10 \mathrm{ml}$, and added $\mathrm{HNO}_{3} 10 \%$ until volume reached $10 \mathrm{ml}$. Finally, the solutions were transferred into a test tube and measured concentration of $\mathrm{Zn}$ and Fe by AAS (Munawar, 2011).

\section{Results and discussion}

Screening of $S$. cerevisiae isolates containing the highest concentration of Fe and $\mathrm{Zn}$

S. cerevisae was reported able to decrease aflatoxin $\mathrm{B} 1$ residue in chicken feed (Kusumaningtyas et al., 2006a; Kusumaningtyas et al., 2006b). The study was conducted to explore other potentials of $\mathrm{S}$. cerevisae to change $\mathrm{Fe}$ and $\mathrm{Zn}$ in inorganic form to organic form by passing in $S$. cerevisae metabolism. Organic minerals from $S$. cerevisae are relatively more secure than inorganic minerals as feed supplements. Minerals in inorganic form are difficult to be absorbed by intestine because they can form complex with other substance and quickly secreted along with faeces. In other hands, organic minerals, called also bioplex, are more stable and will not interfere with absorption process of amino acids (Blazejak \& Reinhard 2004; Korniewicz et al. 2007).

Naturally, S. cerevisae use $\mathrm{Zn}$ and Fe for cell growth and development. A single cell needs $1.5 \times 10^{7}$ zinc atoms for growing optimally so that if the amount is less, the cell growth will be inhibited (Simm et al. 2007). S. cerevisae also releases $\mathrm{Fe}$ compounds proven by presence of additional $\mathrm{Fe}$ in various food products contaminated by $S$. cerevisae (Aguilar et al. 2009). Natural concentrations of Fe and $\mathrm{Zn}$ were also found in all isolates (Figure 1). The graphs show that each isolate has different natural content of $\mathrm{Fe}$ and $\mathrm{Zn}$. Concentrations of $\mathrm{Fe}$ and $\mathrm{Zn}$ in all isolates are respectively around 0.72 to $2.66 \mathrm{ppm}$ and 0.49 to $1.80 \mathrm{ppm}$. These differences of natural mineral content may cause by genetic and physiology of isolates. Unfortunately, the experiments conducted previously have not given satisfactory explanation of the differences of natural mineral content. Figure 1 show that $S$. cerevisae BCC F0206 content of highest of natural level of $\mathrm{Fe}$ and $\mathrm{Zn}$ with concentration $\mathrm{Fe}$ is $2.66 \mathrm{ppm}$ and $\mathrm{Zn}$ is $1.80 \mathrm{ppm}$. 

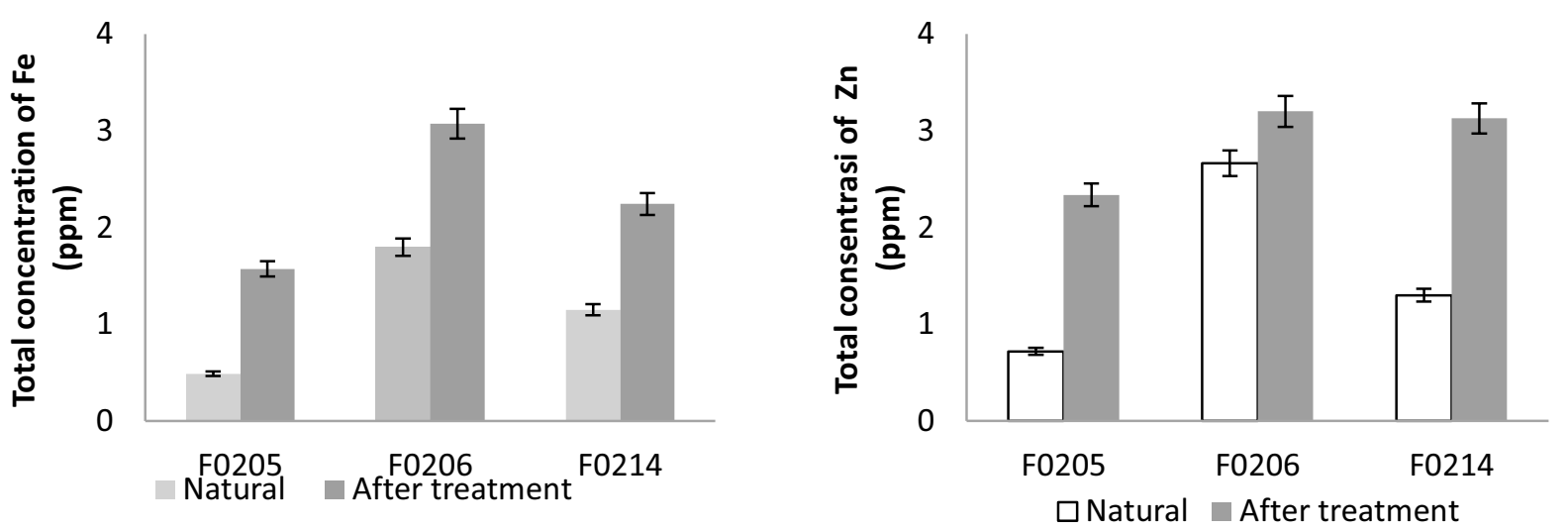

Figure 1 Total concentrations of $\mathrm{Fe}(\mathrm{a})$ and $\mathrm{Zn}(\mathrm{b})$ from $\mathrm{S}$ cerevisae naturally and after treatment with $10 \mathrm{ppm}$ of $\mathrm{Fe}$ or $\mathrm{Zn}$

After treatment, $\mathrm{Fe}$ and $\mathrm{Zn}$ in all isolates increased significantly at around 1.57 to $3.01 \mathrm{ppm}$ for Fe and 2.34 to $3.20 \mathrm{ppm}$ for $\mathrm{Zn}$. This indicated that all isolates have ability to absorb $\mathrm{Fe}$ and $\mathrm{Zn}$ differently from media. S. cerevisae BCC F0205 is isolate which has the highest ability to absorb Fe and $\mathrm{Zn}$ (Figure 1). Enhancement of absorption is almost 2 times for $\mathrm{Fe}(0.72 \mathrm{ppm}$ to $1.57 \mathrm{ppm})$ and almost 5 times for $\mathrm{Zn},(0.47$ ppm to $2.34 \mathrm{ppm}$ ). However, factually, total concentration of Fe and $\mathrm{Zn}$ in BCC F0205 is still lower than other two isolates. For instance, BCC F0206 contained total concentration $3.07 \mathrm{ppm}$ for $\mathrm{Fe}$ and $3.20 \mathrm{ppm}$ for $\mathrm{Zn}$, and BCC F0214 contained total concentration $2.24 \mathrm{ppm}$ for $\mathrm{Fe}$ and $3.13 \mathrm{ppm}$ for $\mathrm{Zn}$. Thus, BCC F0206 is the most potent to generate organic form of $\mathrm{Fe}$ and $\mathrm{Zn}$ because this isolate has natural content and absorption ability was higher than the others. S. cerevisae BCC F0206 was used in the next treatment to find out its maximum absorption by addition various concentration of Fe and $\mathrm{Zn}$ to medium.

\section{Absorption ability of $\mathrm{S}$. cerevisae with various concentrations of $\mathrm{Fe}$ and $\mathrm{Zn}$ in medium}

In figure 2, the graph show that SFe1 absorbed Fe around 0.64 to $2.65 \mathrm{ppm}$ (mean $1.45 \mathrm{ppm}$ ). These ranges of concentrations are higher than the other treatments, SFe2 (0.03 to $1.11 \mathrm{ppm}$, mean $0.50 \mathrm{ppm}$ ) and SFe3 ( 0.02 to $1.69 \mathrm{ppm}$, mean $0.94 \mathrm{ppm}$ ), although the existing concentration of $\mathrm{Fe}$ in media is lower than both SFe2 and SFe3. Therefore, S. cerevisae BCC F0206 absorbed Fe optimally in media containing Fe 2.5 ppm.

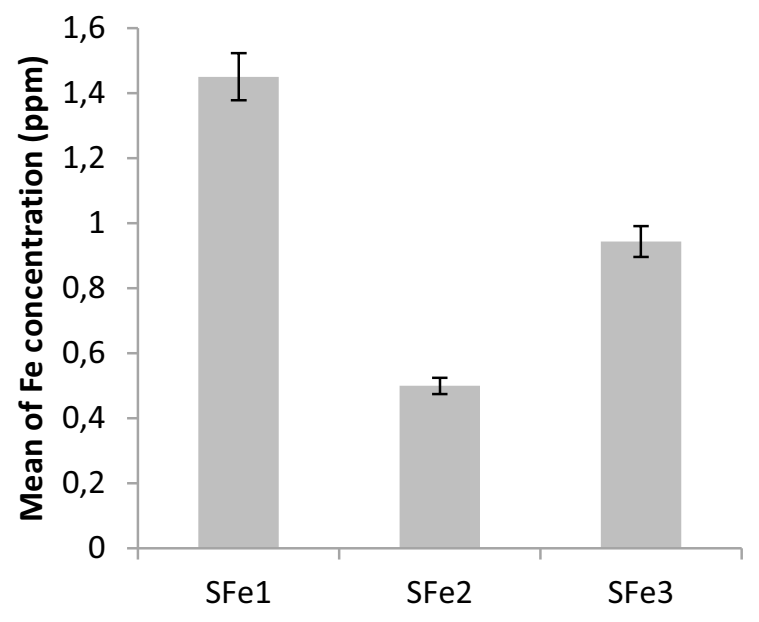

Figure 2 Mean of Fe concentration absorbed by S. cerevisae BCC F0206 from media PDB containing Fe: 2.5,5,10 ppm 
Then, in figure 2, S. cerevisae BCC F0206 is able to absorb Zn from media. SZn1 absorb Zn higher than SZn2 and SZn3. SZn1 absorbed $\mathrm{Zn}$ from 0.38 to $1.18 \mathrm{ppm}$ (mean $0.70 \mathrm{ppm}$ ), but for SZn2 and SZn3 respectively capable to absorb from 0.25 to $0.50 \mathrm{ppm}$ (mean $0.38 \mathrm{ppm}$ ) and from 0.39 to $0.79 \mathrm{ppm}$ (mean $0.53 \mathrm{ppm}$ ). Overall, BCC F0206 absorbed Zn optimally in media containing Zn 2.5 ppm.

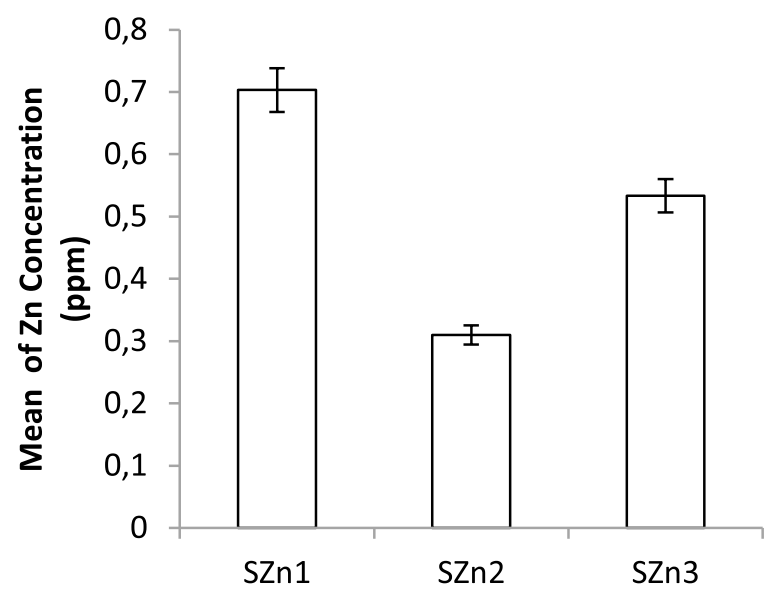

Figure 3 Mean of Zn concentration absorbed by S. cerevisae BCC F0206 from media PDB containing $\mathrm{Zn}: 2.5,5,10 \mathrm{ppm}$

According to the results, the availability concentration of $\mathrm{Fe}$ or $\mathrm{Zn}$ in media can affect the absorption of Fe and $\mathrm{Zn}$ by S. cerevisae BCC F0206. Varieties of these data are strongly influenced not only by genetic and physiology of isolate but also by environment conditions such as mineral content in media. Effect of interaction between Fe and Zn to absorption

In this part, the experiment did further to determine whether interaction is synergistic or antagonistic. Figure 4 show that the more concentrations of $\mathrm{Fe}$ and $\mathrm{Zn}$ were added in media, the more concentration was absorbed by S. cerevisae BCC F0206. The ranges of absorbed concentrations are from 3.10 to $3.67 \mathrm{ppm}$ for Fe and from 0.11 to 0.28 ppm for Zn. However, Fe or Zn was absorbed differently when they were added together into media compared with they were added separately. The highest absorption of $\mathrm{Fe}$ in single treatment is $1.67 \mathrm{ppm}$ while the highest absorption of $\mathrm{Fe}$ in combination treatment is $3.67 \mathrm{ppm}$ obviously there is enhancement more than 2 times. In other hand, in Zn cases, the highest absorption of $\mathrm{Zn}$ in single treatment is $0.79 \mathrm{ppm}$ while the highest absorption of $\mathrm{Fe}$ in combination treatment is $0.28 \mathrm{ppm}$ so that there is decline more than 3 times. These results show that there are antagonistic interactions between $\mathrm{Fe}$ and $\mathrm{Zn}$ during absorption. In addition, the same results were also reported by Evans \& \& Johnson (1980); Gordon (1983) that supremacy of Fe can inhibit Zn but others reported that there is no interaction between Fe and Zn (Momcilovic at al. 1977; Gruden \& Momcovic 1979; Pallauf \& Kirchgessner 1974; Fairweather-Tait et al. 1984).

In addition, table 2 shows that $S$. cerevisae absorb $\mathrm{Fe}$ in combination treatments (SnFeZn1, SnFeZn2, and SnFeZn3) higher than in single treatment (SFe1, SFe2, and $\mathrm{SFe} 3$ ). The percentages of $S$. cerevisae in single treatments were able to absorb up to $100 \%$ but in combination treatments, it can absorb Fe more than $150 \%$. In other hands, $S$. cerevisae can absorb in combination treatments up to $10.40 \%$, lower than in single treatments up to $47.20 \%$. According to results, the maximum absorption of $\mathrm{Zn}$ can be increased if the concentration of $\mathrm{Fe}$ in medium was reduced whereas presence of Zn could support Fe absorption. 


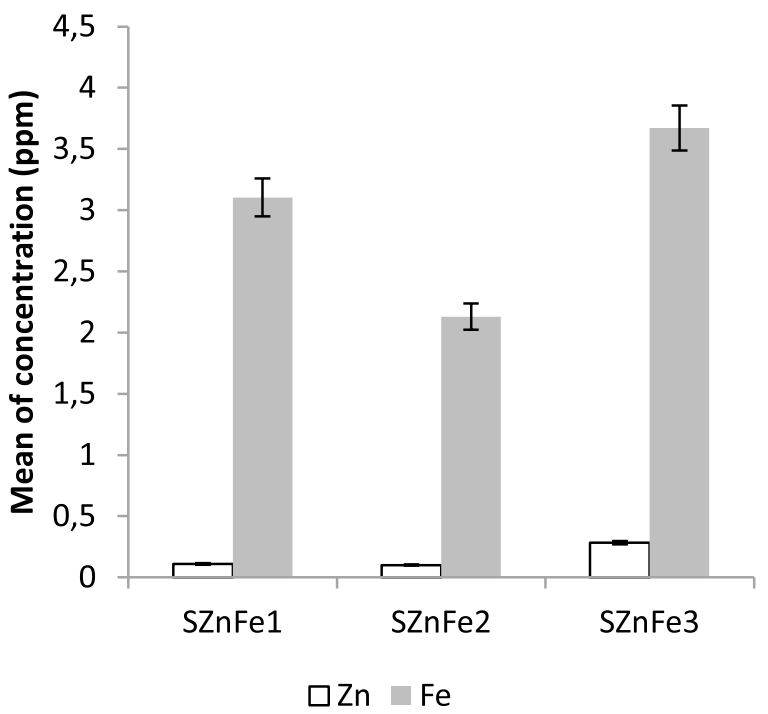

Figure 4. Mean of Fe and Zn concentration absorbed by S. cerevisae BCC F0206 from media PDB containing combination Fe and Zn: 2.5: 2.5, 5:5, 10:10 ppm

Table 2 percentages of absorption of $\mathrm{Fe}$ and $\mathrm{Zn}$ by S. cerevisae BCC F0206

\begin{tabular}{lllllll}
\hline \multirow{2}{*}{ Treatment } & \multicolumn{1}{c}{ Fe } & \multicolumn{1}{c}{ Zn } \\
\cline { 2 - 7 } & \multicolumn{1}{c}{ Range (\%) } & \multicolumn{1}{c}{ Mean (\%) } & \multicolumn{1}{c}{ SD } & Range (\%) & Mean (\%) & SD \\
\hline SFe1 & $25.60-100$ & 56 & 0.39 & & & \\
SFe2 & $0.60-22.20$ & 10 & 0.11 & & & \\
SFe3 & $0.20-16.90$ & 9,43 & 0.084 & & & \\
SZn1 & & $15.20-47.20$ & 28.13 & 0.17 & & \\
SZn2 & & $5.00-10.20$ & 7.60 & 0.037 & & \\
SZn3 & & $3.90-7.90$ & 5.37 & 0.022 & & \\
SZnFe1 & $63.20-187.20$ & 124.13 & 0.62 & $1.20-10.40$ & 4.4 & 0.0052 \\
SZnFe2 & $24.00-58.20$ & 42.6 & 0.17 & $1.40-2.60$ & 2 & 0.006 \\
SZnFe3 & $23.70-46.60$ & 36.7 & 0.11 & $2.20-3.30$ & 2.83 & 0.0056 \\
\hline
\end{tabular}

$1=2.5 \mathrm{ppm}, 2=5 \mathrm{ppm}, 3=10 \mathrm{ppm}$

\section{Conclusion}

Saccharomyses. cerevisae BCC F0206 absorb Fe and Zn higher than BCC F0205 and BCC F0214. The percentages of Fe absorbed are up to $100 \%$ and $\mathrm{Zn}$ absorbed is up to $47.20 \%$ by S. cerevisae BCC F0206. There are antagonistic interactions between $\mathrm{Fe}$ and $\mathrm{Zn}$ in this study so to obtain absorption of Zn optimally, it should be better added separately.

\section{Acknowledgement}

The authors gratefully acknowledge the support by Indonesian Agency for Agricultural Research and Development (IAARD), Munistry of Agiculture, within APBN 2014 project. Special gratitude and appreciation is addressed to the staff $s$ of Indonesian Research Centre for Veterinary Science (IRCVS), Edi Supriadi (Technician of Toxicology Laboratory), Ermayati and Wawan Sugiawan (Technician of Mycology Laboratory).

\section{References}

Ackland, M.L. and Michalczyk, A. 2006. Zinc Deficiency and its Inherited Disorders- A review. Genes \& Nutrition 1 (1) : 41-50

Addai, K.N. 2014. Multi Nutrient Block Supplementation for Ruminants: Formulation and Manufacturing. Journal of Chemistry and Biochemistry $2(1)$

Aguilar, F., Charrondiere, U.R., Dusemund, 
B., Galtier, P., Gilbert, J., Gott, D.M., Grilli, S., Parent-Massin,Guertler, R., Kass, G.E.N., Koenig, J., Lambré, C., Larsen, J-C., Leblanc, J-C., Mortensen, A., Pratt, D I., Rietjens, I.M.C.M., Stankovic, I., Tobback, P., Verguieva, T., Woutersen, R. 2009. SCIENTIFIC OPINION : Inability to assess the safety of iron-enriched yeast as a source of iron, added for nutritional purposes to foods for particular nutritional uses and foods (including food supplements) intended for the general population, based on the supporting dossiers Scientific Statement of the Panel on Food Additives and NutrientSources added to Food (ANS). The EFSA Journal 1130: $1-8$

Arredondo, M., and Nunez, M.T. 2005. Review : Iron and copper metabolism. Molecular Aspects of Medicine 26 : 313-327

Blazejak, S. and Reinhard, W.D. 2004. Yeat Cell Biomass as a Potential Source of Magnesium Bioplexes-A Review. Pol. J. Food Nutr. Sci. (13/54) 3 : 223-232

Evans, G. W. \& Johnson, E. C. 1980. Zinc absorption in rats fed a low-protein diet and a low protein diet supplemented with tryptophan or picolinic acid. J. Nutr. 110: 1076-1080.

Fairweather-Tait, S. J., Payne, V.,Williams, C. M. 1984. The effect of iron supplements on pregnancy in rats given a low-zinc diet. Br. J. Nutr. 52 : 79-86.

Gordon, D. T. 1983. Interaction of iron and zinc on bioavailablity of each element in the rat. Fed. Proc. $42: 1184$

Gruden, N. \& Momcovic, B. 1979. Zn transport in the duodenum and jejunum of rats fed milk enriched with iron. Nutr. Rep. Int. 19 : 483-489.

Hegoczki, 1994 in Gudreau H, Tompkins TA and Champagne CP. 2001. he distribution of iron-enriched cells of Sacharomyces cerevisiae. Act alimentaria 30(4): 355-361

Jang, Y.D., Kang, K.W., Piao, L.G., Jeong, T.S., Aauclair, E., Jonvel, S., D'Inca, RR., Kim, Y.Y. 2013. Effects of live yeast supplementation to gestation and lactation diets on reproductive performance, immunological parameters and milk composition in sows. Livestock Science. 152 :
167-173

King, J.C. 2000. Determinants of maternal zinc status during pregnancy. $A m \mathrm{~J}$ Clin Nutr 71: 1334S-43S

King, M.W. 2006. Clinical aspect of iron metabolism. J. Med. Biochem. 15 (9) : 1- 4

Knutson, M., and Wessling-Resnick, M. 2003. Iron Metabolism in the Reticuloendothelial System. Critical Reviews in Biochemistry and Molecular Biology, 38(1):61-88

Korniewicz, D., Dobrzanski, Z., Chojnacka, K., Korniewicz, A., Kolacz, R. 2007. Effect of Dietary Yeasts Enriched with $\mathrm{Cu}, \mathrm{Fe}$ and $\mathrm{Mn}$ on Digestibility of Main Nutrients and Absorption of Minerals by Growing Pigs. Am. J. Agril. \& Biol. Sci., 2 (4): 267-275

Kumar, S., Pandey, A.K., Razzaque, W.A.D., and Dwivedi, D.K. 2011. Importance of micro minerals in reproductive performance of livestock. Veterinary World 4 (5) : 230-233

Kusumaningtyas, E., Widiastuti, R., Maryam, R. 2006a. Reduction of Aflatoxin $\mathrm{B} 1$ and $\mathrm{M} 1$ residues in duckc liver by giving culture of Saccharomyces cerevisiae and Rhizopus oligosporus. Prosiding: Seminar Nasional Teknologi Peternakan dan Veteriner. 790 -795

Kusumaningtyas, E., Widiastuti, R., Maryam, R. 2006b. Reduction of aflatoxin B1 in chicken feed by using Saccharomyces cerevisiae, Rhizopus oligosporus and their combination. Mycopathologia 162: 307-311

Maliken, B.D., Nelson, J.E., Klintworth, H.M., Beauchamp, M., Yeh, M.M., and Kowdley, K.V. 2013. Hepatic Reticuloendothelial System Cell Iron Deposition is Associated with Increased Apoptosis in Nonalcoholic Fatty Liver Disease. Hepatology 57(5): 1806-1813

Momcilovic, B. \& Kello, D. 1977. The effect of milk enriched with iron on $\mathrm{Zn}$ absorption. Nutr. Rep. Int. 14 : 651657.

Munawar, H. 2011. Comparison of Multi and Single Element Standards Used to Analyze Zinc(Zn) In Chicken and Beef. Proceeding : Seminar Nasional Teknologi Peternakan dan Veteriner.765-771

Nadadur, S.S., Srirama, K., and Mudipalli, A. 
2008. Iron transport \& homeostasis mechanisms: Their role in health and disease. Indian J Med Res 128 : 533544

Pallauf, J. and fit Kirchgessner, M. 1974. Zinc status in depletion and repletion and its relation to vitamins and trace minerals. In: Trace Element Metabolism in Animals-2 (Hoekstra, W. G.,Suttie, J. W., Ganter, H. E. fit Mertz, W., eds.), University Park Press, Baltimore, MD.

Roy, S.K., Tomkins, A.M., Ara, G., Jolly, S.P., Khatun,W., Chowdhury, R., Chakrabarty, B. 2006. Impact of Zinc Deficiency on Vibrio cholerae Enterotoxin-stimulated Water and Electrolyte Transport in Animal Model. J Health Popul Nutr 24(1):4247.

Sillerova, S., Blazena, L., Dana, U., Anezka P. Alena V, L'uboš H. 2012. Preparation of Zinc Enriched Yeast (Saccharomyces cerevisiase) by Cultivation with defferent Zinc Salts. Journal of Microbiology, Biotechnology and Food Sciences. 1:689-695

Simm, C., Lahner, B., Salt, D., LeFurgey, A., Ingram, P., Yandell, B., Eide, D.J. 2007. Saccharomyces cerevisiae Vacuole in Zinc Storage and Intracellular Zinc Distribution. ASM, Eukaryotic Cell 6 (7) : 1166-1177

WHO, UNICEF and UNU. 2001. Iron Deficiency Anaemia Assessment, Prevention, and Control. A guide for programme managers .WORLD HEALTH ORGANIZATION. http://www.who.int/nutrition/publicatio ns/en/ida_assessment_prevention_c ontrol.pdf

Widhyari, S.D. 2012. The role and deficiency of zinc mineral in immune system. 